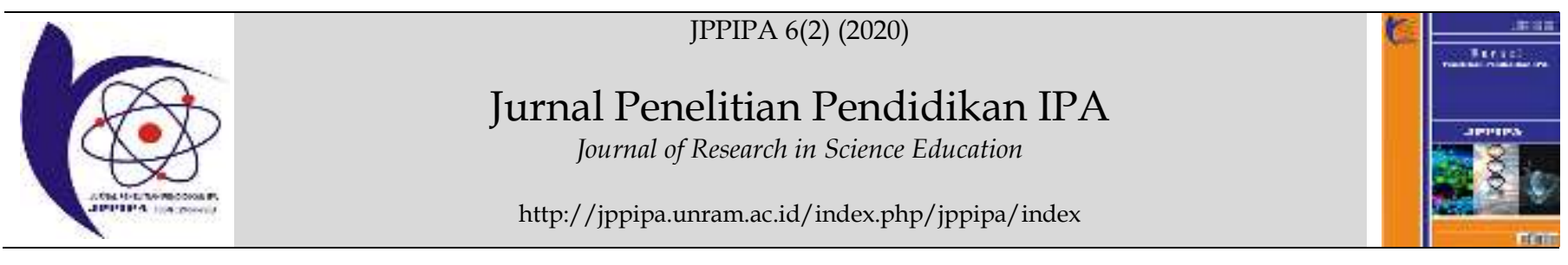

\title{
Synthesis of $\mathrm{SnO}_{2}$ Thin Coatings by Indium and Aluminum Mixed Doping using the Sol-Gel Spin-Coating Technique
}

\author{
Haris Munandar ${ }^{*}$, Aris Doyan ${ }^{1,2}$, Susilawati ${ }^{1,2}$ \\ ${ }^{1}$ Master of Science Education Program, University of Mataram, Lombok, West Nusa Tenggara, Indonesia. \\ ${ }^{2}$ Physics Education, Faculty of Teacher Training and Education, University of Mataram, Lombok, West Nusa Tenggara, Indonesia.
}

\section{DOI: $10.29303 /$ ippipa.v6i2.391}

\section{Article Info}

Received : February $4^{\text {th }}, 2020$

Revised : May $21^{\text {th }}, 2020$

Accepted: June 9th, 2020

\begin{abstract}
This research succeeded in creating a thin layer of $\mathrm{SnO}_{2}$ and $\mathrm{SnO}_{2}$ : $\mathrm{In}+\mathrm{Al}$ through a synthesis process with the sol-gel spin-coating technique on a glass substrate. The manufacture of this thin layer uses the basic material $\mathrm{SnCl}_{2} \cdot 2 \mathrm{H}_{2} \mathrm{O}$, and the doping material $\mathrm{InCl}_{3} .4 \mathrm{H}_{2} \mathrm{O}$ and $\mathrm{AlCl}_{3}$. This thin layer is made with variations in doping concentration, number of layers, and heating temperature. The results of the synthesis of $\mathrm{SnO}_{2}$ : In+Al films show that the thin film formed is more transparent when the doping concentration and the number of layers is increased. Meanwhile, the thin layer that forms is increasingly not transparent when heated at higher temperatures.
\end{abstract}

Keywords: Thin layer; $\mathrm{SnO}_{2}$; Indium; Aluminum; Sol-Gel; Spin-Coating.

Citation: Munandar, H., Doyan, A., \& Susilawati, S. (2020). Synthesis of $\mathrm{SnO}_{2}$ Thin Coatings by Indium and Aluminum Mixed Doping using the Sol-Gel Spin-Coating Technique. Jurnal Penelitian Pendidikan IPA (JPPIPA). 6(2), 153-156. doi: https://doi.org/10.29303/jppipa.v6i2.391

\section{Introduction}

Current technology is developing very rapidly and produces a very small technology, namely nanotechnology. Nanotechnology was introduced by Michael Faraday since 1850 and continues to develop (Battal et al, 2014, Doyan, et al, 2019). One form of nanotechnology is a thin film. The thin layer continues to experience growth both in terms of the way it is made, the materials used, and its application in people's lives (Mak \& Shan, 2016). Equipment used by many people uses thin layers, such as LCD TVs, plasma TVs, touch screen handphones (cellphones) and automatic teller machines (ATMs), handheld game consoles, and car navigation systems. In addition, thin films are also used in semiconductor devices such as diodes, capacitors, sensors, and transistors (Anaraki et al, 2016). Thin films can be made from inorganic, organic, metal, metal-organic mixtures, and metalinorganic mixtures. Thin films have sizes on the nanometer scale (Mihailescu, 2019). Thin films can be as an insulator, conductor, semiconductor, or superconductor (Mak \& Shan, 2016).

Making thin films usually uses materials such as $\mathrm{In}_{2} \mathrm{O}_{3}, \mathrm{ITO}, \mathrm{SnO}_{2}, \mathrm{TiO}_{2}, \mathrm{WO}_{3}, \mathrm{ZnO}$ (DeAngelis, 2018). $\mathrm{SnO}_{2}$ is often used as a base for making thin films. This is related to its superiority in nature like its reflectivity, transparency, and low electrical resistance. In addition, $\mathrm{SnO}_{2}$ thin films have high chemical stability and good transparency properties to light with an energy gap of $\sim 3.6 \mathrm{eV}$ (Carvalho et al, 2012). $\mathrm{SnO}_{2}$ thin film is widely applied in the manufacturing industry of transparent electrodes, solar cells, optical-electrical equipment, and gas sensors. This is based on the cheap price compared to other semiconductors, can to respond to some gases properly, has a long service life, and only requires simple electronic devices in the implementation of sensing. In addition, the properties of $\mathrm{SnO}_{2}$ are very dependent on the crystallographic quality and surface morphology of deposited layers (Morales et al, 2015). Experimental results show that materials such as $\mathrm{TiO}_{2}$, $\mathrm{ZnO}$, and $\mathrm{SnO}_{2}$ are proven capable of detecting $\mathrm{O}_{2}, \mathrm{CO}$, 
and several types of hydrocarbon gases (Mishra at al, 2017).

Pure or doped $\mathrm{SnO}_{2}$ thin films have been produced through various techniques, such as sol-gel spin coating to synthesize $\mathrm{SnO}_{2}$ thin films with Aluminum doping (Doyan et al, 2017), pyrolysis spray to synthesize $\mathrm{SnO}_{2}$ thin films with Fluorine doping (Bakr et al, 2016), synthesis of $\mathrm{SnO}_{2}$ by doping Fluorine using the sol-gel spin-coating technique (Susilawati et al, 2019), and sol-gel dip coating to synthesize the $\mathrm{SnO}_{2}$ thin layer (Carvalho et al, 2012). The synthesis of $\mathrm{SnO}_{2}$ doped Indium thin films tends to be more transparent when the doping concentration is increased and will become less transparent when the heating temperature is increased (Hakim et al, 2019). The effect of the addition of aluminum doping concentrations on the quality of transparency of $\mathrm{SnO}_{2}$ thin-film was also proven to increase the level of transparency (Imawanti et al, 2017).

This study will use the sol-gel spin coating technique because it has several advantages, namely having a short crystallization process, the use of low temperatures, nanoparticles, pure yields, economic and simple in nature (Yati et al, 2017; Doyan et al, 2019). Some of the variables involved in the sol-gel spin coating technique are solution concentration, doping concentration, rotational speed, turnaround time, solution aging time, layer repetition, and heat treatment (Doyan et al, 2017).

\section{Method}

The basic material used as a coating in this study was 0.902 grams of Tin (II) chloride dihydrate $\left(\mathrm{SnCl}_{2} .2 \mathrm{H}_{2} \mathrm{O}\right.$ with a molar mass of $225.63 \mathrm{grams} / \mathrm{mol}$, 98\% purity, Merck). The solvent uses $40 \mathrm{ml}$ of ethanol $\left(\left(\mathrm{C}_{2} \mathrm{H}_{5} \mathrm{OH}\right)\right.$ with a molar mass of $46.07 \mathrm{gram} / \mathrm{mol}, 98 \%$ purity, Merck) at room temperature. The ingredients for doping are $0.4266 ; 0.8532 ; 1.2797 ; 1.7063$; and 2.1329 grams In+Al. The substrate used is glass with a size of $10 \mathrm{~mm} \times 10 \mathrm{~mm} \times 3 \mathrm{~mm}$. Other supporting materials are aquades water, detergent soap, and alcohol which are used to clean substrates. $\mathrm{SnO}_{2}$ : $\mathrm{In}+\mathrm{Al}$ thin film synthesis includes substrate preparation, sol-gel manufacturing, thin-film manufacturing, and the heating process.

Substrate preparation is done by washing the glass substrate using detergent soap, then stirring using a shaker for 30 minutes. After that, rinse it using distilled water, and soak it using alcohol for 30 minutes. Then heat it using the furnace for one hour at $100{ }^{\circ} \mathrm{C}$ (Doyan and Humaini, 2017).

Making sol-gel is done by mixing $\mathrm{SnCl}_{2} \cdot 2 \mathrm{H}_{2} \mathrm{O}$ with $\mathrm{InCl}_{3} .4 \mathrm{H}_{2} \mathrm{O}$ and $\mathrm{AlCl}_{3}$ with a mixture concentration of $1 \mathrm{M}$, so as to produce $\mathrm{SnO}_{2}$ sol-gel doped with Indium and Aluminum with different concentrations. Comparison of $\mathrm{SnO}_{2}: \mathrm{In}+\mathrm{Al}$ concentrations in this thin layer is $100: 0 \%, 95: 5 \%$, $90: 10 \%, 85: 15 \%, 80: 20 \%, 75: 25 \%$. After mixing, the ingredients are stirred using a magnetic stirrer to produce a homogeneous solution. After stirring, the solution is allowed to stand for 24 hours.

Making thin films is done by the sol-gel spincoating technique using a spin coater. $\mathrm{SnO}_{2}$ : $\mathrm{In}+\mathrm{Al}$ solution is dropped on a glass substrate, then rotated using a spin coater at $2000 \mathrm{rpm}$ for 2 minutes. Samples were made as many as 120 samples, with variations in doping concentration, number of layers, and heating temperature. After all, samples have been rotated, they are stored at different temperatures, namely room temperature, $50{ }^{\circ} \mathrm{C}, 100{ }^{\circ} \mathrm{C}, 150{ }^{\circ} \mathrm{C}$, and $200{ }^{\circ} \mathrm{C}$. Each sample at this temperature amounted to 24 samples.

\section{Result and Discussion}

The process of making $\mathrm{SnO}_{2}$ : $\mathrm{In}+\mathrm{Al}$ thin films consists of the stages of substrate preparation, sol-gel manufacturing, thin-film manufacturing, and the heating process. The substrate used is glass. The glass is washed first to ensure the glass is clean of other substances. After that, the glass is heated to vaporize the remnants of other substances attached to the glass.

The next step is the process of making sol-gel by mixing $\mathrm{SnCl}_{2} \cdot 2 \mathrm{H}_{2} \mathrm{O}$ with $\mathrm{InCl}_{3} \cdot 4 \mathrm{H}_{2} \mathrm{O}$ and $\mathrm{AlCl}_{3}$ with a mixture concentration of $1 \mathrm{M}$ using ethanol solvent. The amount of ethanol used as a solvent is $20 \mathrm{ml}$ (Muliyadi et al, 2019). The amount of $\mathrm{SnCl}_{2} \cdot 2 \mathrm{H}_{2} \mathrm{O}$, $\mathrm{InCl}_{3} .4 \mathrm{H}_{2} \mathrm{O}$, and $\mathrm{AlCl}_{3}$ dissolved in $20 \mathrm{ml}$ of ethanol in order to obtain the desired concentration ratio can be seen in Table 1. The results of the $\mathrm{SnO}_{2}: \mathrm{In}+\mathrm{Al}$ solution formed by the sol-gel technique can be seen in Figure 1 .

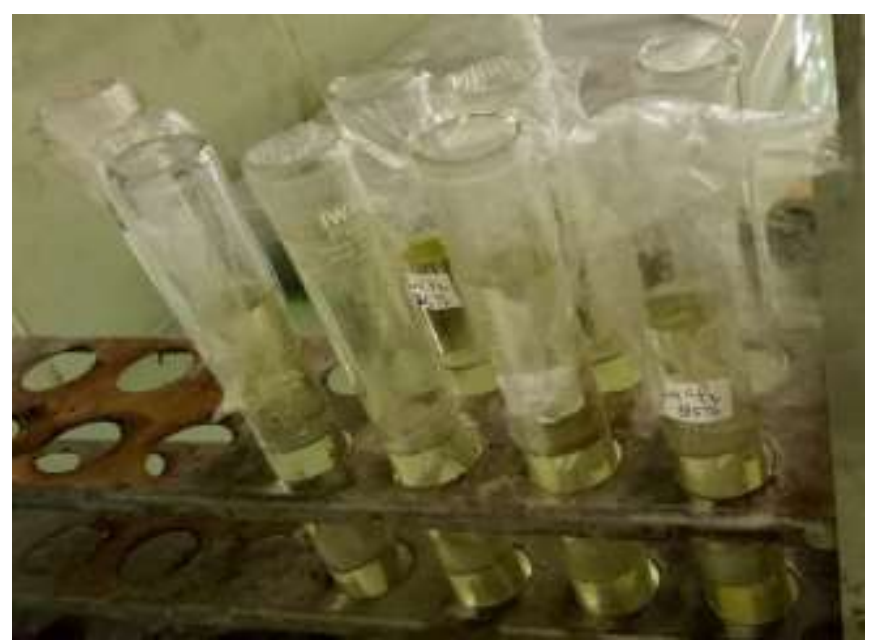

Figure 1. $\mathrm{SnO}_{2}: \mathrm{In}+\mathrm{Al}$ solution with different doping concentrations. 
Table 1. Comparison of mass composition of thin film $\mathrm{SnO}_{2}: \mathrm{In}+\mathrm{Al}$

\begin{tabular}{llll}
\hline $\begin{array}{l}\mathrm{SnO}_{2}: \mathrm{In}+\mathrm{Al} \\
(\%)\end{array}$ & $\begin{array}{l}\mathrm{SnCl}_{2} \cdot 2 \mathrm{H}_{2} \mathrm{O} \\
\text { (gram) }\end{array}$ & $\begin{array}{l}\mathrm{InCl}_{3} .4 \mathrm{H}_{2} \mathrm{O} \\
\text { (gram) }\end{array}$ & $\begin{array}{l}\mathrm{AlCl}_{3} \\
\text { (gram) }\end{array}$ \\
\hline $100: 0$ & 4.5125 & 0.0000 & 0.0000 \\
$95: 5$ & 4.2869 & 0.1466 & 0.0667 \\
$90: 10$ & 4.0613 & 0.2932 & 0.1335 \\
$85: 15$ & 3.8356 & 0.4398 & 0.2000 \\
$80: 20$ & 3.6100 & 0.5865 & 0.2667 \\
$75: 25$ & 3.3844 & 0.7331 & 0.3334 \\
\hline
\end{tabular}

The next process is the manufacture of thin films using spin-coating techniques. The glass substrate is placed on a spin coater, then drops of $\mathrm{SnO}_{2}: \mathrm{In}+\mathrm{Al}$ solution. Glass substrate that has been dropped by $\mathrm{SnO}_{2}: \mathrm{In}+\mathrm{Al}$ solution is rotated at $2000 \mathrm{rpm}$ for 2 minutes. This screening is intended so that the $\mathrm{SnO}_{2}$ : $\mathrm{In}+\mathrm{Al}$ solution is spread evenly on the glass substrate.

After all, samples have been rotated, the process of adding layers and heating the samples at different temperatures is carried out. It aims to determine the effect of many layers and heating temperature on the quality of the thin film formed. Previous research has proven that the concentration of doping Indium (Hakim et al, 2019) and Aluminum doping (Imawanti et al, 2017) and different heating temperatures have an effect on the quality of the thin film formed. In other research, it has been proven that the more concentration of doping Aluminium and Zinc which is added to $\mathrm{SnO}_{2}$, the more transparency of the thin films which is produced (Ikraman et al, 2017, Doyan et al, 2017).

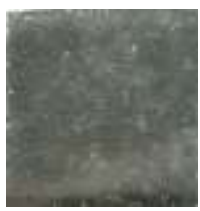

(a)

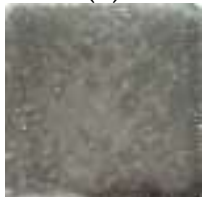

(d)

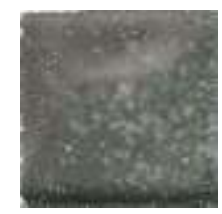

(b)

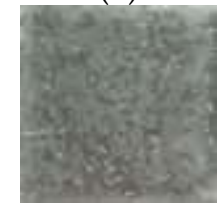

(e)

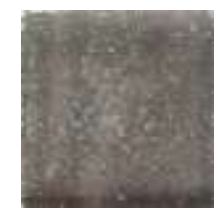

(c)

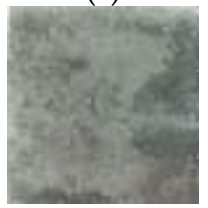

(f)
Figure 2. $\mathrm{SnO}_{2}: \mathrm{In}+\mathrm{Al}$ thin film at $50{ }^{\circ} \mathrm{C}$ with 3 layers in various $\mathrm{SnO}_{2}: \mathrm{In}+\mathrm{Al}$ concentrations (a) 75:25\%, (b) 80:20\%, (c) $85: 15 \%$, (d) $90: 10 \%$, (e) 95:5\%, (f) 100:0\%.

Figure 2 shows that the $\mathrm{SnO}_{2}: \mathrm{In}+\mathrm{Al}$ thin films from the picture (a) to picture (f) experience a decreasing level of transparency. This shows that $\mathrm{SnO}_{2}$ : In+Al thin films with higher doping concentrations have higher transparent levels.

The number of layers in a thin layer also affects the transparency level of the thin film. The results of the synthesis of $\mathrm{SnO}_{2}: \mathrm{In}+\mathrm{Al}$ thin films with different amounts of layers can be seen in Figure 3.

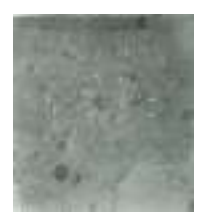

(a)

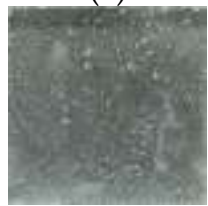

(c)

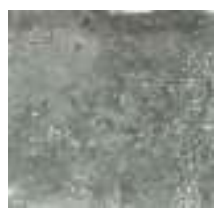

(b)

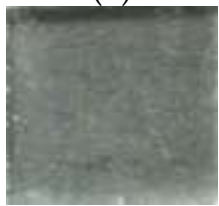

(d)
Figure 3. $\mathrm{SnO}_{2}: \mathrm{In}+\mathrm{Al}$ thin layer at $100{ }^{\circ} \mathrm{C}$ with a concentration of $\mathrm{SnO}_{2}: \mathrm{In}+\mathrm{Al}=95: 5 \%$ with variations in the number of layers (a) 1, (b) 2, (c) 3, (d) 4 .

Figure 3 shows that the $\mathrm{SnO}_{2}: \mathrm{In}+\mathrm{Al}$ thin film formed is more transparent when the number of layers is added. This proves that the number of layers in the thin layer has an effect on the level of transparency.

In addition to doping concentration and the number of layers, the heating temperature also affects the transparency quality of the formed $\mathrm{SnO}_{2}: \mathrm{In}+\mathrm{Al}$ films. The results of the synthesis of thin films at different temperatures can be seen in Figure 4 .

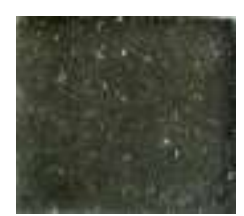

(a)

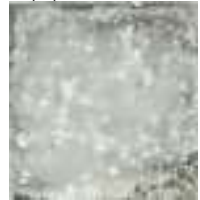

(d)

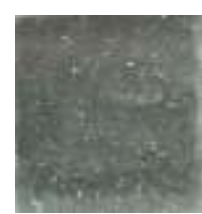

(b)

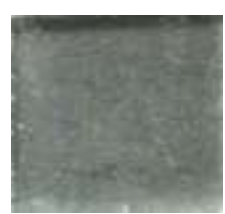

(c)

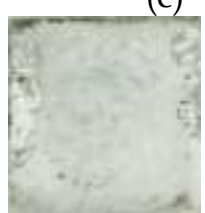

(e)
Figure 4. $\mathrm{SnO}_{2}$ :In+Al thin film with the 4 layers with a $\mathrm{SnO}_{2}$ concentration: $\mathrm{In}+\mathrm{Al}=95: 5 \%$ at temperature (a) room temperature, (b) $50{ }^{\circ} \mathrm{C}$, (c) $100{ }^{\circ} \mathrm{C}$, (d) $150{ }^{\circ} \mathrm{C}$, (e) $200{ }^{\circ} \mathrm{C}$.

Figure 4 shows that from the picture (a) to picture (e) the $\mathrm{SnO}_{2}$ : $\mathrm{In}+\mathrm{Al}$ thin layer is becoming less transparent. This shows that the addition of the heating temperature makes the $\mathrm{SnO}_{2}$ : $\mathrm{In}+\mathrm{Al}$ thin layer more transparent.

\section{Conclusion}

The process of making sol-gel can take place normally at room temperature. The sol-gel spin-coating technique is good and efficient for making thin-film samples. The thin film produced by the sol-gel spin- 
coating technique has good surface properties. The surface quality of $\mathrm{SnO}_{2}: \mathrm{In}+\mathrm{Al}$ films produced is influenced by doping concentration, the number of layers, and heating temperature. The more concentration and the number of layers makes the level of transparency of the thin layer higher. Meanwhile, the thin layer becomes less transparent when the heating temperature is increased.

\section{Acknowledgements}

My best thanks for my lectures who have guided me in finishing this research. Thank you to the Master of Science Education Program, Postgraduate University of Mataram which always facilitates the administration of this research. Furthermore, thank you to the Ministry of research and technology of higher education who have provided research funding assistance through the Student Thesis Research scheme along with the research of the supervisor so that this thesis can be completed.

\section{References}

Anaraki, E. H., Kermanpur, A., Steier, L., Domanski, K., Matsui, T., Tress, W., Correa-Baena, J.P. (2016). Highly efficient and stable planar perovskite solar cells by solution-processed tin oxide. Energy $\mathcal{E}$ Environmental Science, 9 (10): 3128-3134. DOI: 10.1039 /c6ee02390h.

Bakr, N. A., Salman, S. A., and Ali, M. N. (2016). Effect of Fluorine Doping on Structural and Optical Properties of $\mathrm{SnO}_{2}$ Thin Films Prepared by Chemical Spray Pyrolysis Method. Advances in Materials, 5(4): 23-30. DOI: 10.11648/j.am.20160504.12.

Battal, A., Tatar, D., Kocyigit, A., and Duzgun B. (2014). Comparison Effect of Spin Speeds and Substrate Layers on Properties of Doubly Doped Tin Oxide Thin Films Prepared by Sol-Gel Spin Coating Method. Journal of Ovonic Research, 10 (2): 23-34.

Carvalho, D.H.Q., Schiavon, M.A., Raposo, M.T., De Paiva, R., Alves, J.L.A., Paniago, R.M., and Ardisson, J.D. (2012_. Synthesis and characterization of $\mathrm{SnO}_{2}$ thin films prepared by the dip-coating method. Physics Procedia, 28, 2227. DOI: $10.1016 / j$.phpro.2012.03.664.

DeAngelis, A. D., Horsley, K., \& Gaillard, N. (2018). Wide Band Gap $\mathrm{CuGa}(\mathrm{S}, \mathrm{Se})_{2}$ Thin Films on Transparent Conductive Fluorinated Tin Oxide Substrates as Photocathode Candidates for Tandem Water Splitting Devices. The Journal of Physical Chemistry C, 122(26), 14304-14312. DOI: 10.1021/acs.jpcc.8b02915.
Doyan, A., and Humaini. (2017). Optical Properties of Thin Films ZnO. Journal of Physics Education and Technology, 3 (1): 34-39.

Doyan, A., Susilawati, and Imawanti, Y. D. (2017). Synthesis and Characterization of $\mathrm{SnO}_{2}$ Thin Layer with a Doping Aluminum are Deposited on Quartz Substrates. American Institute of Physics, 1801: 1-7. DOI: 10.1063/1.4973083.

Doyan, A., Susilawati, Fitri, S. A., and Ahzan, S. (2017). Cristal Structure Characterization of Thin Layer Zinc Oxide. Materials Science and Engineering, 196: 1-6. DOI:10.1088/1757-899X/196/1/012004.

Doyan, A., Susilawati, Ikhraman, N., Taufik, M., (2017). Characterization of $\mathrm{SnO}_{2}$ Film with $\mathrm{Al}-\mathrm{Zn}$ Doping Using Sol-Gel Dip Coating Techniques. The International Conference on Theoretical and Applied Physics, 040007-1 - 040007-7, ISSN:17426588E-ISSN:1742-6596.

Doyan, A., Susilawati, Harjono, A., Azzahra, S., Taufik, M., (2019). Characterization of Tin Oxide Doping Antimony Thin Layer with Sol-Gel Spin Coating Method for Electronic Device. Materials Science and Engineering, 282-289. DOI: 10.4028/www.scientific.net/MSF.966.30

Doyan, A., Susilawati, Hakim, S., Muliyadi, L., Taufik, M., and Nazarudin. (2019). The Effect of Indium Doped $\mathrm{SnO}_{2}$ Thin Films on Optical Properties Prepared by Sol-Gel Spin Coating Technique. Journal of Physics: Conference Series. ICRIEMS 6. DOI: 10.1088/1742-6596/1397/1/012005.

Hakim, S., Doyan, A., Susilawati, and Muliyadi, L. (2019). Synthesis Thin Films $\mathrm{SnO}_{2}$ with Doping Indium by Sol-Gel Spin Coating. Journal of Science Education Research, 5 (2): 171-174. DOI: 10.29303/jppipa.v5i2.254.

Ikraman, N., Doyan, A., and Susilawati. (2017). Growing the $\mathrm{SnO}_{2}$ Film with Al-Zn Doping Using Sol-Gel Dip Coating Technique. Journal of Physics Education and Technology, 3 (2): 228-231.

Imawanti, Y. D., Doyan, A., and Gunawan, E. R. (2017). Synthesis of $\mathrm{SnO}_{2}$ and $\mathrm{SnO}_{2}$ Thin Films: Al Using the Sol-Gel Spin Coating Technique on Glass and Quartz Substrate. Journal of Science Education Research, 3 (1): 1-9.

Mak, K. F., \& Shan, J. (2016). Photonics and optoelectronics of 2D semiconductor transition metal dichalcogenides. Nature Photonics, 10(4), 216-226. DOI: 10.1038/nphoton.2015.282.

Mihailescu, I. N. (2019). Synthesis and Modification of Nanostructured Thin Films. Nanomaterials, 9: 1427. DOI:10.3390/nano9101427.

Mishra, R. K., Murali, G., Kim, T.-H., Kim, J. H., Lim, Y. J., Kim, B. S., and Lee, S. H. (2017). Nanocube $\mathrm{In}_{2} \mathrm{O}_{3}$ RGO heterostructure based gas sensor for acetone and formaldehyde detection. RSC 
Advances, $\quad 7(61), \quad 38714-38724 . \quad$ DOI:

$10.1039 / \mathrm{c} 7 \mathrm{ra} 05685 \mathrm{k}$.

Morales-Masis, M., Dauzou, F., Jeangros, Q., Dabirian, A., Lifka, H., Gierth, R., Ballif, C. (2015). An Indium-Free Anode for Large-Area Flexible OLEDs: Defect-Free Transparent Conductive Zinc Tin Oxide. Advanced Functional Materials, 26 (3): 384-392. DOI: 10.1002/adfm.201503753.

Muliyadi, L., Doyan, A., Susilawati, and Hakim, S. (2019). Synthesis of $\mathrm{SnO}_{2}$ Thin Layer with a Doping Fluorine by Sol-Gel Spin Coating Method. Journal of Science Education Research, 5 (2): 175-178. DOI: 10.29303/jppipa.v5i2.257.

Susilawati, Doyan, A., Muliyadi, L., Hakim, S., Taufik, M., and Nazarudin. (2019). Characteristic and Optical Properties of Flourine Doped $\mathrm{SnO}_{2}$ Thin Film Prepared by a Sol-Gel Spin Coating. Journal of Physics: Conference Series. ICRIEMS 6. DOI: 10.1088/1742-6596/1397/1/012003.

Yati, B. Y, Rubianto, A. L, Atiek, R. N, and Nia, K. (2017). Tin Dioxide Thin Films As Carbon Monoxide Sensor. Journal of Chemistry Education. DOI: 10.24114/jpkim.v9i1.6189. 